\title{
Some Properties of a New Bacteriocin Formed by Bacillus megaterium
}

\author{
BY I. B. HOLLAND AND C. F. ROBERTS \\ Microbiology Unit, Department of Biochemistry, University of Oxford
}

(Received 21 November 1963)

\begin{abstract}
SUMMARY
A new bacteriocin, megacin $C$, was recognized in certain strains of Bacillus megaterium; it was initially observed as the agent responsible for killing sensitive organisms in mixed culture. The bacteriocin was liberated during growth of cultures; but later, after reaching a maximum value, it disappeared from the culture media. Megacin $\mathrm{C}$ was produced by strains already known to produce another bacteriocin, megacin $\mathbf{A}$. The activity spectra of the two megacins differed markedly and non-megacin $\mathbf{A}\left(M_{A^{-}}\right)$ mutants still produced megacin C. A preliminary grouping of megacin types is proposed. Megacin A is comparable to the original megacin first studied by Ivánovics \& Alföldi (1954). Megacin A produced inhibition zones surrounding colonies on solid medium but its formation in liquid medium required induction with ultraviolet (u.v.) radiation. Megacin B, whose activity spectra differed from those of megacins $\mathbf{A}$ and $\mathbf{C}$, can be detected only on a solid medium; it is not formed in liquid culture even after u.v.-irradiation. Megacin $\mathbf{C}$ can be detected only on a particular solid medium and its formation in liquid media is not induced by u.v.irradiation.
\end{abstract}

\section{INTRODUCTION}

Bacteriocins are substances, produced by many bacteria, which are highly specific antibacterial proteins active against strains of the homologous species (Jacob, Lwoff, Siminovitch \& Wollman, 1953). Sensitive bacteria may be killed by the adsorption of a few molecules of bacteriocin to specific receptor sites, but the actual mode of action is not yet understood. The wide distribution of bacteriocins has been reviewed by Hamon \& Peron (1963) and their general properties by Ivánovics (1962). The bacteriocins most extensively studied are the colicins produced by members of the family Enterobacteriaceae (Fredericq, 1957). Several different colicins have been isolated or partially purified and in each case the active protein has been found to be associated with a lipo-polysaccharide protein complex identifable with a cell wall component (Nüske, Hösel, Venner \& Zinner, 1957; Goebel \& Barry, 1958; Hutton \& Goebel, 1961; Barry, Everhart \& Graham, 1963). This suggests that colicins may be 'normal' components of the cell envelope of colicinogenic strains. In some cases the production of colicin may be induced by ultraviolet (u.v.) irradiation (Fredericq, 1954, 1955; Kellenberger \& Kellenberger, 1956). Since it has been shown that both spontaneous and induced formation, i.e. leading to release of soluble colicin, can be lethal to the producing organisms (Ozeki, Stocker \& de Margerie, 1959) it might be suggested that this is the result of a de-repressed and uncontrolled formation of a normally minor cell wall component, rather than a 
unique synthesis of protein. Ability to produce colicin is determined by a genetic factor (colicinogenic factor) which behaves as a cytoplasmic element and which can be transferred from colicinogenic $\left(\mathrm{col}^{+}\right)$to non-colicinogenic $\left(\mathrm{col}^{-}\right)$bacteria by cell to cell contact (Fredericq \& Betz-Bareau, 1953a, $b, 1956$; Alföldi, Jacob \& Wollman, 1957). Some colicinogenic factors also facilitate transmission of chromosomal genes from $\mathrm{col}^{+}$to $\mathrm{col}^{-}$organisms (Ozeki, Howarth \& Clowes, 1961). Thus the distinction between $\mathrm{col}^{+}$factors and fertility $(F)$ factors is, in fact, only marginal (see Sneath, 1962).

Bacteriocinogenic strains of Bacillus megaterium were first reported by Ivánovics \& Alföldi (1954) but only one type of megacin has so far been described. This megacin is inducible by u.v.-radiation (Ivánovics \& Alföldi, 1955) and is a simple protein free from lipopolysaccharide (Holland, 1961). The bacteriocin acts by destroying the cytoplasmic membrane of sensitive bacteria (Ivánovics, Alföldi \& Nagy, 1959 $a$; Holland, 1962).

This paper describes evidence of some new types of megacin and suggests a classification. The demonstration of the new megacin arose out of studies of the possible function of megacinogenic factors as fertility agents in Bacillus megaterium. In a preliminary communication (Holland \& Roberts, 1963) we reported a killing effect by certain megacin-producing strains which was apparently manifest through the actual contact of megacinogenic and non-megacinogenic bacteria. We have now been able to show that the killing activity was due to a hitherto undetected megacin. The production and mode of action of this new bacteriocin, megacin $\mathrm{C}$, are quite different from those of previously reported megacins.

\section{METHODS}

Organisms. The following organisms used in this work were obtained from other laboratories as follows. Escherichia coli $\mathrm{K} 12$ and Salmonella typhimurium 903 from Dr R. C. Clowes; Bacillus megaterium Mut. and the lysogenic B. megaterium strain 10 from Professor A. Lwoff; B. megaterium De Bary and B. cereus strains 8012 and 8122 from the National Collection of Industrial Bacteria (NCIB); B. subtilis 1379 from Dr R. G. Tucker; B. cereus 7587 and $B$. subtilis 8236 from the National Collection of Type Cultures (NCTC); B. megaterium strain 207-M and strain 216 were described previously (Holland, 1961); two non-megacin A producing mutants,

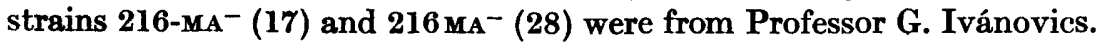

The remaining strains of Bacillus megaterium were isolated by the present authors. Soil samples in distilled water were heated at $80^{\circ}$ for $15 \mathrm{~min}$. and after standing for $60 \mathrm{~min}$. the large debris was removed by decantation and a loopful of each remaining suspension spread on plates of nutrient broth agar. After incubation for $20 \mathrm{hr}$ at $37^{\circ}$ one colony was taken from each plating and purified by streaking out twice on nutrient broth agar. Criteria for the identification of $B$. megaterium included acetylmethylcarbinol production, colonial form, cellular morphology and motility. Megacinogenic strains were tested and all found to grow on a defined medium (Alföldi, 1958).

Recognition of megacinogenic organisms. Large colonies (5-6 mm. diam.) of different strains of Bacillus megaterium were obtained by stabbing cultures into nutrient broth agar plates and incubating for $36 \mathrm{hr}$ at $37^{\circ}$. The organisms were 
killed with a heavy dose of ultraviolet (u.v.) radiation which would also inactivate most bacteriophages produced by lysogenic strains. The irradiated colonies were then overlayered with a phage-resistant megacin-sensitive strain (B. megaterium 207-M) from an overnight culture diluted 20-fold in fresh broth before use. After $14 \mathrm{hr}$ at $37^{\circ}$ the irradiated colonies which produced inhibition zones in the overlay, i.e. $\boldsymbol{M}^{+}$strains, were noted.

U.v.-irradiation. The source of u.v.-radiation was a Hanovia Chromatolite(Holland, 1961). For killing large colonies and the irradiation of spore suspensions the lamp was set at 25 and $50 \mathrm{~cm}$., respectively, and the irradiation was continued for $10 \mathrm{~min}$.

Isolation of mutants. Non-megacinogenic mutants $\left(M^{-}\right)$of strains producing megacin A were isolated from irradiated spore suspensions as described by Ivánovics $\&$ Nagy (1958). Streptomycin-resistant mutants $(S R)$ were selected by progressive exposure to increasing concentrations of streptomycin; nutrient broth (50 ml.) was inoculated with an overnight culture and streptomycin (final concentration $1 \mu \mathrm{g} . /$ ml.) added after $4 \mathrm{hr}$ incubation at $37^{\circ}$. The culture was allowed to reach to the stationary phase and this was used as inoculum for the successive treatment with streptomycin at 2, 5 and $10 \mu \mathrm{g} . / \mathrm{ml}$. The resistant strain was plated on nutrient broth agar + streptomycin to $10 \mu \mathrm{g} . / \mathrm{ml}$., purified by re-streaking twice and its properties compared with those of the parent organism.

Determination of antibacterial spectra of different megacins. Stab cultures of $\mathbf{M}^{+}$ strains which produced $\mathbf{A}$ and $\mathbf{B}$ megacins were set up as already described and overlayered with an overnight culture (diluted 20-fold in fresh broth) of different strains. After incubation for $14 \mathrm{hr}$ at $37^{\circ}$ the activity spectrum for each producing strain was determined, from the inhibition zones produced, after examination under standard lighting conditions. For determination of megacin $\mathrm{C}$ activity, stab cultures of $\mathrm{MA}^{-}$organisms were set up on Oxoid nutrient agar plates and incubated for 24 $\mathrm{hr}$ at $37^{\circ}$. The macro-colonies were u.v.-irradiated, overlayered and the activity spectra obtained as before.

Measurement of concentration of cultures. The optical density of bacterial suspensions and cultures was determined in an EEL colorimeter, with a neutral density filter.

Media. For the determination of megacin $\mathrm{C}$ activity spectra, Oxoid Nutrient Agar (CM 3; Oxo Ltd., London) was used. The nutrient broth agar, other media and all other general cultural methods were as described previously (Holland, 1961, 1962).

\section{RESULTS}

\section{Grouping of megacinogenic strains of Bacillus megaterium}

Killing in mixed culture by megacinogenic strains. Megacinogenic $\left(M^{+}\right)$strains were initially recognized by their ability to inhibit the growth on solid medium of a standard indicator strain, Bacillus megaterium 207-M. Although free megacin formation in liquid cultures was extremely low or not detectable, it was found that in mixed culture with $\boldsymbol{M}^{+}$strains of $\boldsymbol{B}$. megaterium, the $\boldsymbol{M}^{-}$bacteria were often killed (Holland \& Roberts, 1963). This effect was studied in short-term experiments in which young growing cultures of $\boldsymbol{M}-\boldsymbol{S R}$ (streptomycin-resistant) organisms were mixed with equal numbers of washed $M^{+} S S$ (streptomycin sensitive) organisms. The mixed cultures were incubated and the survival of $M-S R$ organisms determined by plating diluted samples on nutrient broth agar +streptomycin. The results 


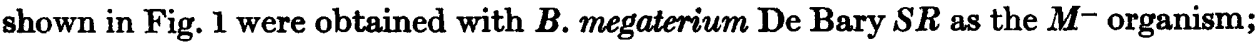
similar results were obtained with two other $M^{-}$strains. The $M^{+}$strains were clearly divisible into three groups: group 1 (non-killers) did not kill the $M$ - bacteria; group 2 (delayed killers) killed the $\boldsymbol{M}$ - bacteria only after the latter had multiplied for 30-45 min.; group 3 (rapid killers) killed the $M^{-}$organisms immediately the two strains were mixed.

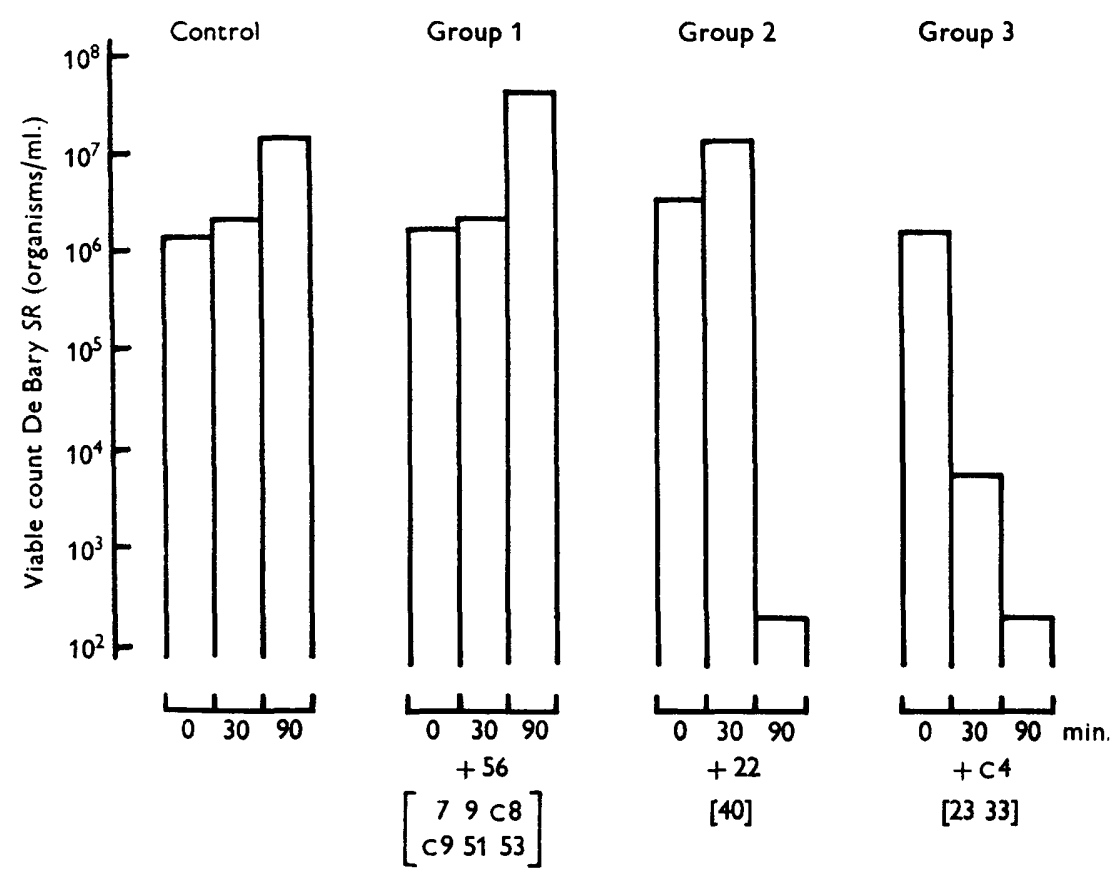

Fig. 1. Preliminary grouping of megacinogenic $\left(M^{+}\right)$strains of Bacillus megaterium after mixed culture with B. megaterium De Bary $S R$. Growing cultures of B. megaterium De Barry $S R$ in nutrient broth were mixed with an equal volume $(5 \mathrm{ml}$.) of different $B$. megaterium $\boldsymbol{M}^{+}$strains. The $\boldsymbol{M}^{+}$organisms were washed once, resuspended to a final concentration of about $10^{\circ}$ organisms/ml. in warm $\left(37^{\circ}\right)$ broth before mixing. Samples were taken at intervals, diluted and plated on nutrient broth agar + streptomycin $10 \mu \mathrm{g} . / \mathrm{ml}$. The viable count of strain De Bary $S R$ was determined after $14 \mathrm{hr}$ at $37^{\circ}$; 1 strain from each $M^{+}$group is illustrated, strains giving similar results are in brackets; control, untreated.

Inducibility of $\boldsymbol{M}^{+}$strains of Bacillus megaterium. As already stated megacinogenic strains usually form no detectable megacin when grown in liquid media, but with some strains megacin formation can be induced under such conditions by u.v.irradiation (Ivánovics \& Alföldi, 1955). All the $\boldsymbol{M}^{+}$strains were therefore also tested for u.v. inducibility. Young growing cultures (EEL reading, 0.5) were irradiated in a warm Petri dish for $1 \mathrm{~min}$. under conditions described previously (Holland, 1961). Irradiated and non-irradiated control cultures were re-incubated and their growth followed with an EEL absorptiometer. Finally, the organisms were removed by centrifugation and the supernatant fluids assayed with the megacin-sensitive indicator strain 207-M. Representative results are shown in Fig. 2 ; in every case the $M^{+}$strains behaved in a characteristic way according to the 
group to which they had already been assigned. Group 1 strains (non-killers) were not inducible; group 3 strains (rapid killers) were all inducible and lysed about 90 min. after u.v.-irradiation, releasing large amounts of megacin; group 2 strains (delayed killers) also lysed about $90 \mathrm{~min}$. after irradiation but there was no increase in megacin titre. It was found subsequently that non-megacinogenic mutants of delayed killers no longer lysed after u.v.-induction (Fig. 6). It appears therefore that the $M$ factor is defective in some way in the parent strain. Thus although the expression of the $\boldsymbol{M}^{+}$factor on induction of group 2 strains led to lysis of the bacteria, no active megacin was released.

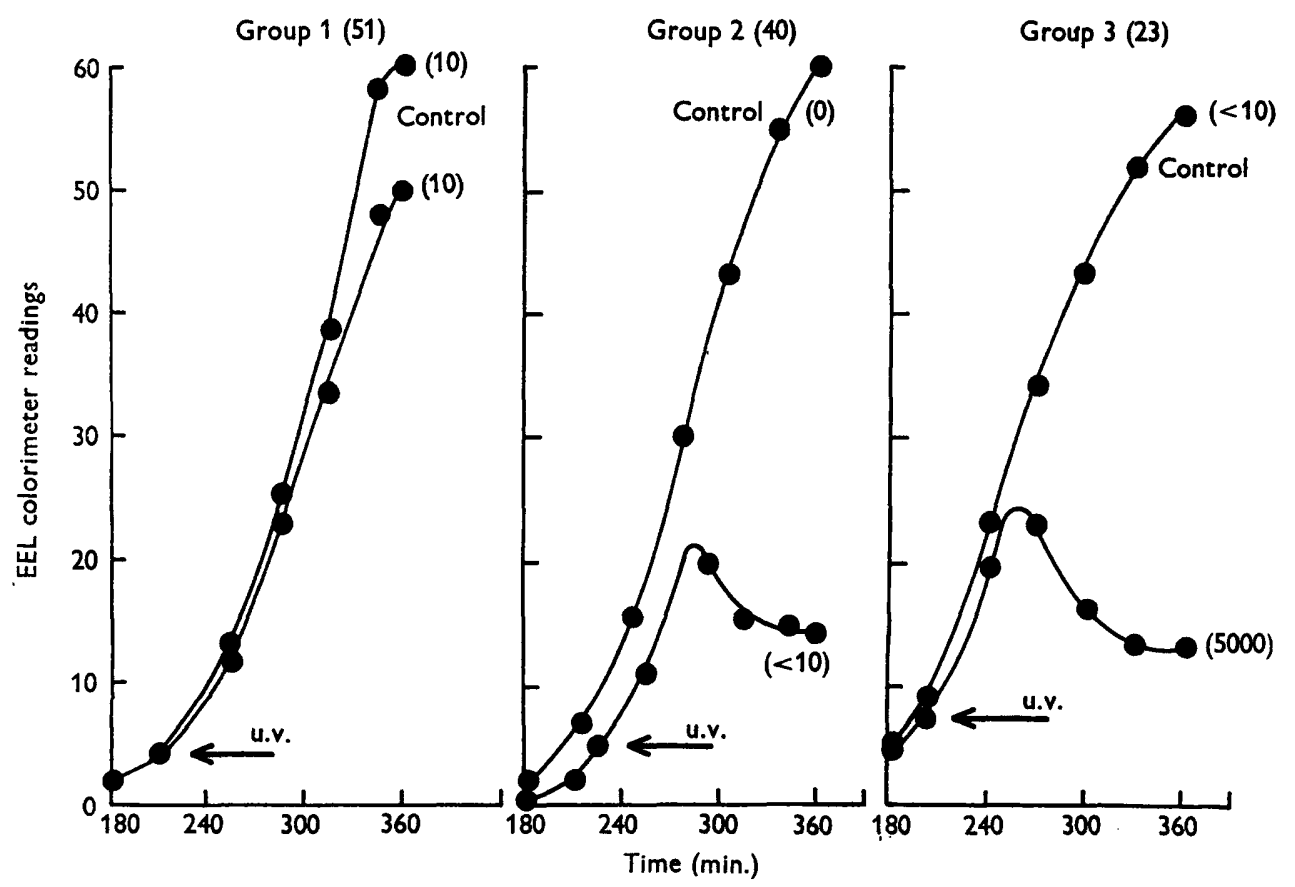

Fig. 2. Response to u.v. irradiation of different groups of megacinogenic strains of Bacillus megaterium. Young cultures of B. megaterium $M^{+}$strains growing in nutrient broth were u.v.-irradiated for 60 sec., re-incubated at $37^{\circ}$ and growth followed in an EEL absorptiometer. Results with one strain from each group are shown; controls, unirradiated. The figures by the curves are megacin titres, in units/ml. of the final supernatant fluids, with $B$. megaterium $207-M$ as indicator organism.

The strains of group 3 (rapid killers) and group 2 (delayed killers) behaved essentially like the u.v.-inducible strains described by Ivánovics and his co-workers (cf. Ivanovics, 1962); the megacin they produce will be described as megacin $A$. The group 1 strains (non-killers) will be described as megacin B producers.

\section{The nature of killing in mixed culture by strains of Bacillus megaterium which produced megacin $A$}

Although killing was associated with certain megacinogenic strains, several pieces of evidence indicated that megacin $\mathbf{A}$ itself was not responsible. No antibacterial agent was detected in the supernatant fluids from the mixed cultures or in cultures 
of the killer strain alone when these were tested against two megacin-sensitive indicator strains, Bacillus megatarium 207-M and Mut. Moreover, strains either resistant or sensitive to megacin $A$ in plate tests were killed with equal rapidity in mixed culture. Finally, no killing took place when organisms were grown in a common medium but separated by bacterial filters; this indicated that close contact of $M^{+}$and $M^{-}$bacteria was necessary for killing (Holland \& Roberts, 1963).

The effect of 'concentration' of killer strain on the survival of sensitive organisms. The effect of the number of organisms present of the rapid killer strain Bacillus megaterium c $4(S S)$ on the survival of the $M^{-}$strain $B$. megaterium Mut. SR was

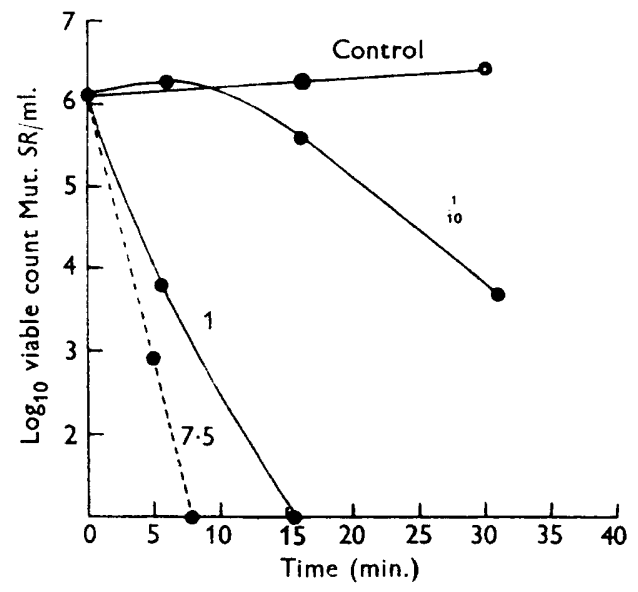

Fig. 3

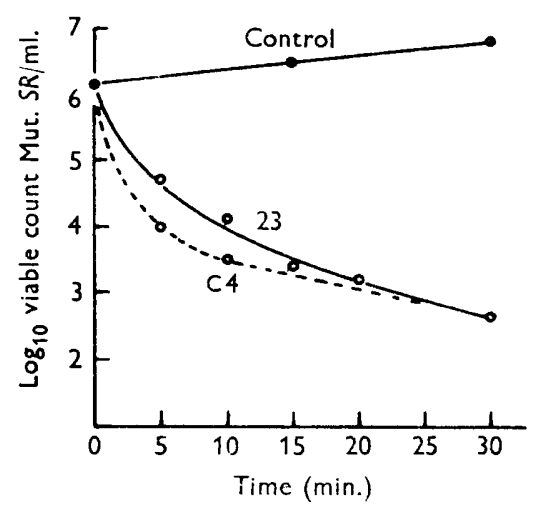

Fig. 4

Fig. 3. Effect of number of organisms of $M^{+}$, Bacillus megaterium $\mathrm{c} 4$ (Group 3) on the survival in mixed culture of B. megaterium Mut. SR. A growing culture of $B$. megaterium c 4 was harvested, washed and resuspended to different concentrations in warm $\left(37^{\circ}\right)$ broth; each suspension mixed with an equal volume $(5 \mathrm{ml}$.) of a growing culture of $B$. megaterium Mut. SR. Survival of B. megaterium Mut. SR was determined as in Fig. 1. Control was strain Mut. SR alone; figures by the curves indicate the ratio, $M^{+}: M^{-}$ organisms present at time 0 .

Fig. 4. Effect on the viability of Bacillus megaterium Mut. SR mixed with non-growing cultures of $\mathrm{M}^{+}$(Group 3) strains $\mathrm{c} 4$ and 23 of $\mathrm{B}$. megaterium. Growth of strains 28 and c 4 was first halted by cooling to $20^{\circ}$, harvested, washed and resuspended in broth at $20^{\circ}$. The non-growing suspensions were added to growing cultures of B. megaterium Mut. SR and the decrease in viability of this organism determined as in Fig. 1. Control, mixed with $5 \mathrm{ml}$. cold $\left(20^{\circ}\right)$ broth at time $0 ; M^{+}: M^{-}=1$.

examined. A growing culture of $\boldsymbol{B}$. megaterium $\mathrm{c} 4$ was harvested by centrifugation, washed with fresh warm broth and finally resuspended in warm broth. The bacteria were mixed with a young growing culture of the sensitive organism and the mixture shaken at $37^{\circ}$. Samples were taken at intervals, diluted and plated on nutrient agar + streptomycin to determine the survival of B. megaterium Mut. SR (Fig. 3). The onset and rate of killing was markedly affected by the relative proportion of $M^{+}$organisms added. At a multiplicity of $7 \cdot 5$ (i.e. $M^{+}: M^{-}$), killing was very rapid and no $M^{-}$bacteria could be recovered after $15 \mathrm{~min}$. At lower multiplicity some increase in viable count of the $\boldsymbol{M}^{-}$organism was observed before killing began and the rate of killing was decreased.

Similar results were observed whether washed or unwashed $\boldsymbol{M}^{+}$bacteria were 
used and whether the experiments were completed in static or in aerated cultures at $37^{\circ}$. It was noted that young cultures of Bacillus megaterium $\mathrm{c} 4$ were sensitive to temperature shock, and harvesting and washing were consequently done with broth, as described above, warmed to $37^{\circ}$. The viable count of cultures washed in broth at $20^{\circ}$ decreased considerably and the culture did not resume growth for several hours after re-incubation. Nevertheless, such 'shocked' cultures still killed

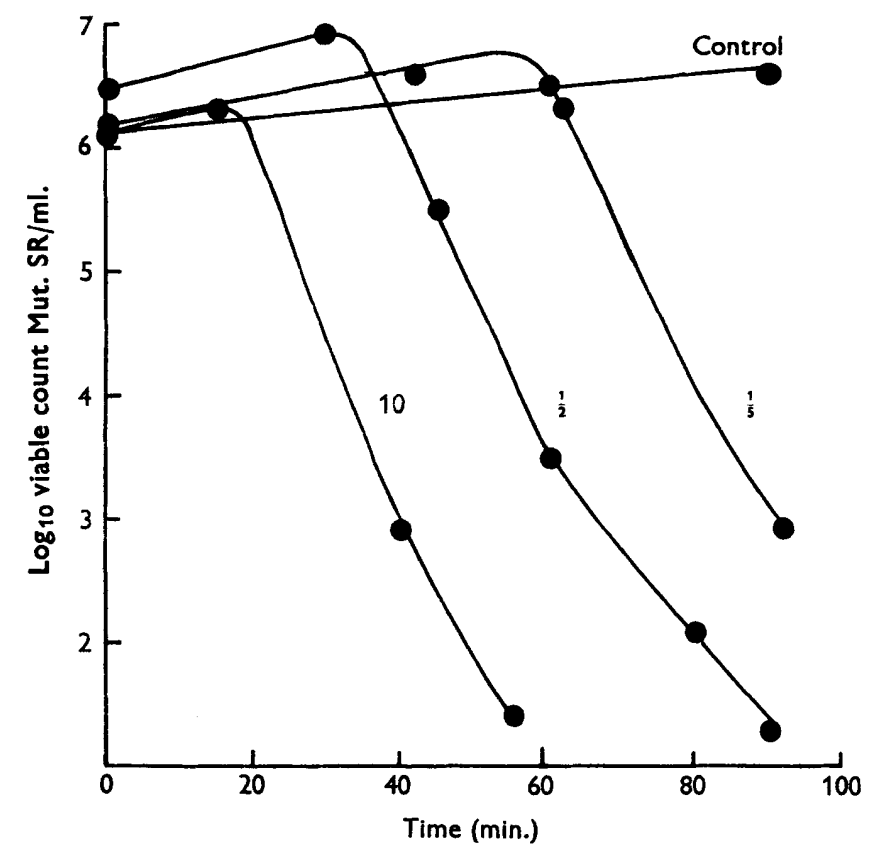

Fig. 5. Effect of the number of organisms of $M^{+}$strain, Bacillus megaterium 22 (group 2) on the survival of B. megaterium Mut. SR in mixed culture. Experiment was carried out as in Fig. 3. Control, B. megaterium Mut. SR growing alone, figures by the curves are the ratio $\mathbf{M}^{+}: M^{-}$organisms present at time 0 .

at an initial rate comparable to that of growing cultures, but killing ceased after 5-10 min. whilst a considerable number of $M^{-}$bacteria survived (Fig. 4). This suggests that a growing culture of $B$. megaterium $\mathrm{c} 4$ was not necessary for killing but that the concentration of the killing agent was limited in non-growing populations. These results, together with the experiments with cultures separated by bacterial filters (see above) and continued failure, at this time, to demonstrate any soluble lethal agent, indicated that the killing factor was something closely associated with the whole organism.

The effect of multiplicity on the killing of Bacillus megaterium Mut. SR in mixed culture with the delayed killer B. megaterium 22 was then tested (Fig. 5). As found previously, with roughly equal amounts of $M^{+}$and $M^{-}$bacteria there was a lag of 30-45 min., whilst the sensitive organism multiplied, before killing began. By adjusting the multiplicity of the killer strain the lag period could be increased or decreased and thus the difference between the delayed and rapid killers made greater or smaller. The distinction between delayed and rapid killing was therefore quantitative rather than qualitative. 


\section{Isolation and properties of non-megacinogenic mutants}

Although megacin $\mathbf{A}$ had been excluded as the killing agent it was possible that the megacinogenic factor itself was responsible, as a result of some form of zygotic induction or lethal zygosis (Jacob \& Wollman, 1961). A series of non-megacinogenic mutants $\left(\boldsymbol{M} \boldsymbol{A}^{-}\right)$of megacin A-producing strains were therefore isolated from heavily irradiated spore suspensions (Table 1). Non-megacinogenic mutants occurred at a
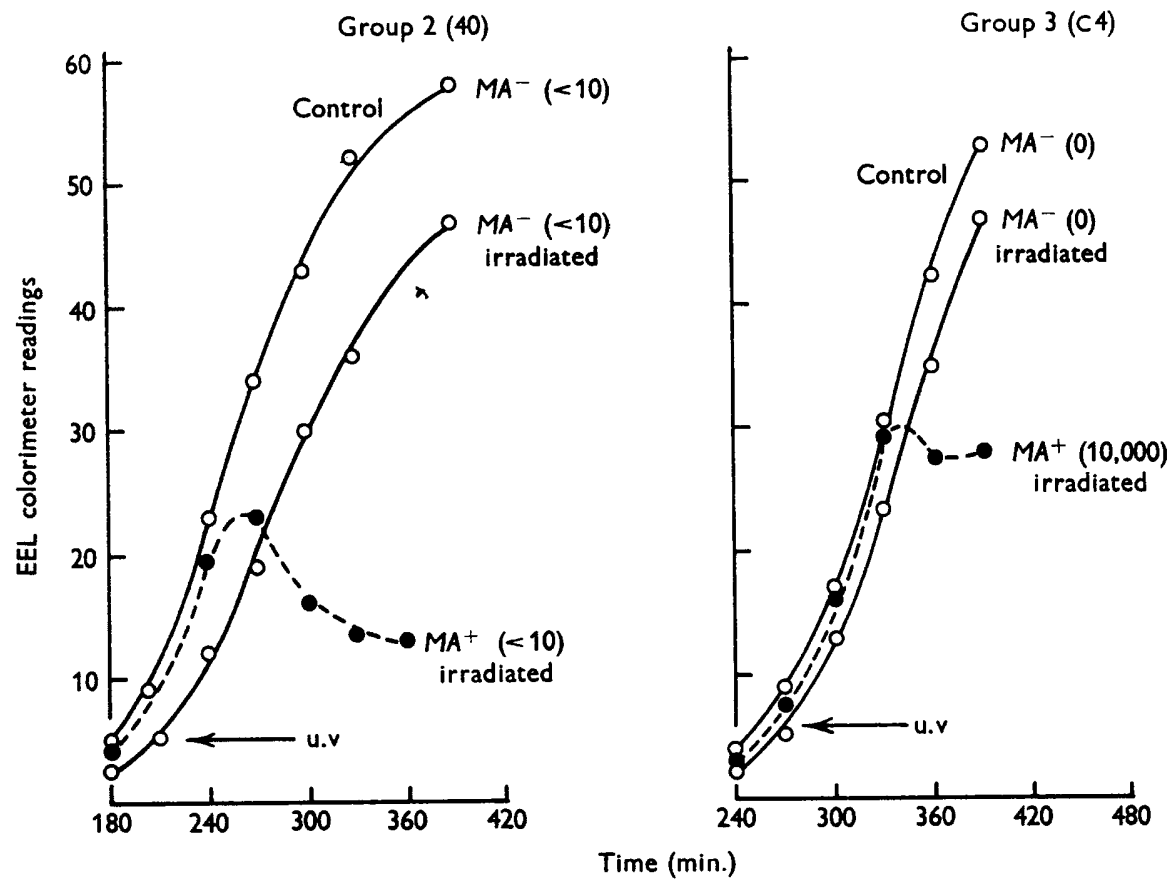

Fig. 6. Response to u.v.-irradiation of MA- mutants of megacinogenic strains of Bacillus megaterium. Induction was carried out as in Fig. 2. Controls, un-irradiated; figures by the curves are the megacin titres, in units $/ \mathrm{ml}$. of the final supernatant fluids when $B$. megaterium 207-M was the indicator bacterium.

\section{Table 1. Isolation of non-megacinogenic mutants of Bacillus megaterium}

Spore suspensions $(10 \mathrm{ml}$.) in distilled water were u.v.-irradiated for $10 \mathrm{~min}$. in open Petri dishes placed $50 \mathrm{~cm}$. from the u.v. source. The proportion of surviving colony formers was about $1 / 1^{4}$; these were plated on nutrient broth agar; after overnight incubation at $37^{\circ}$ the colonies were replicated on to plates previously seeded with the megacinsensitive organism, Bacillus megaterium 207-M. Mutants which produced no inhibition zones were selected.

\begin{tabular}{|c|c|c|c|}
\hline Strain & $\begin{array}{l}\text { No. of spores } \\
\text { irradiated } \\
\text { (per ml.) }\end{array}$ & $\begin{array}{l}\text { Total no. of } \\
\text { surviving } \\
\text { organisms } \\
\text { examined }\end{array}$ & $\begin{array}{l}\text { M- mutants } \\
\text { isolated }\end{array}$ \\
\hline c4 & $3.2 \times 10^{6}$ & 710 & 2 \\
\hline 22 & $2.0 \times 10^{5}$ & 950 & $\mathbf{3}$ \\
\hline 40 & $3.0 \times 10^{6}$ & 634 & 1 \\
\hline 23 & $2.0 \times 10^{6}$ & 960 & 1 \\
\hline 83 & $8.0 \times 10^{5}$ & 410 & 1 \\
\hline
\end{tabular}


high frequency among the surviving populations, a result noted previously by Ivánovics \& Nagy (1958) who used irradiated and non-irradiated spore suspensions. Spontaneous loss of megacinogeny during serial subculture on Oxoid broth agar slopes was also noted. In both cases, in addition to loss of ability to produce megacin A on solid media, the $M A^{-}$mutants, including the group 2 producers (delayed killers), no longer lysed after u.v.-irradiation (Fig. 6). The $\boldsymbol{M} \boldsymbol{A}^{-}$-strains thus appeared to have lost completely the megacin $A$ factor and in the majority of cases the mutants were found to have become very sensitive to the megacin A produced by the parent organism. In these respects therefore megacin A factors behave in the same way as prophage and other episomes (Jacob, Schaeffer \& Wollman, 1960).

Table 2. Killing of Bacillus megaterium Mut. SR by non-megacinogenic mutants in mixed culture

Growing cultures of Bacillus megaterium Mut. SR (about $4 \times 10^{6}$ organisms $/ \mathrm{ml}$.) in nutrient broth were mixed with equal numbers of washed $M^{+} S S$ or $M-S S$ organisms. The mixed cultures were shaken at $B 7^{\circ}$, the viable count of Mut. SR determined at intervals by plating diluted samples on nutrient broth agar +streptomycin $(10 \mu \mathrm{g} . / \mathrm{ml}$.).

\begin{tabular}{|c|c|c|c|c|}
\hline \multirow{2}{*}{$\begin{array}{l}\text { Killer } \\
\text { strain }\end{array}$} & \multicolumn{4}{|c|}{ Time (min.) } \\
\hline & \multicolumn{4}{|c|}{ Viable count Mut. SR (bacteria/ml.) } \\
\hline None & $3 \cdot 3 \times 10^{6}$ & $10^{7}$ & $2.8 \times 10^{7}$ & $\mathbf{3 . 6} \times 10^{7}$ \\
\hline c4 $M^{+}$ & $2.5 \times 10^{6}$ & $<10$ & - & - \\
\hline $\mathbf{C 4} \boldsymbol{M} A^{-}$ & $6.5 \times 10^{6}$ & $<10$ & - & - \\
\hline $23 M^{+}$ & $2.8 \times 10^{6}$ & $1.7 \times 10^{2}$ & 一 & - \\
\hline $23 M A^{-}$ & $2.9 \times 10^{6}$ & $10^{8}$ & $8.0 \times 10^{1}$ & - \\
\hline $33 M^{+}$ & $2.0 \times 10^{6}$ & $10^{1}$ & - & - \\
\hline $33 M^{-}$ & $2.7 \times 10^{6}$ & $10^{8}$ & $<10$ & - \\
\hline $40 M^{+}$ & $2.5 \times 10^{8}$ & $7.5 \times 10^{6}$ & $2.0 \times 10^{6}$ & $5 \cdot 2 \times 10^{4}$ \\
\hline $40 M^{-}$ & $\mathbf{3 . 1} \times 10^{6}$ & $1.6 \times 10^{7}$ & $1.6 \times 10^{7}$ & $4.5 \times 10^{6}$ \\
\hline $22 M^{+}$ & $4.7 \times 10^{5}$ & $2.1 \times 10^{6}$ & $4 \times 10^{2}$ & - \\
\hline $22 M A^{-}$ & $4.8 \times 10^{5}$ & $2.6 \times 10^{6}$ & $4.7 \times 10^{8}$ & - \\
\hline
\end{tabular}

Killing by non-megacinogenic mutants $\left(\boldsymbol{M A ^ { - }}\right)$ in mixed culture. The short-term mixed culture experiments were repeated with different $M A^{-}$strains and the nonproducer Bacillus megaterium Mut. SR (Table 2). In one case, B. megaterium 22 (delayed killer), loss of the $\boldsymbol{M A}$ factor resulted in loss of the ability to kill in mixed culture. However in all other cases $B$. megaterium Mut. SR was killed at rates comparable with those observed with the original strains; in most cases therefore we were able to confirm that some factor other than megacin A or its genetic determinant was concerned in killing.

\section{Demonstration of a new bacteriocin megacin $C$}

The non-megacinogenic mutants $\left(M^{-}\right)$were routinely tested for reversion to wild type and in the course of these tests, after several subcultures, strains Bacillus megaterium $\mathrm{c} 4 M A^{-}$and $33 M A^{-}$were observed to produce a previously undetected antibacterial agent. It was first noted on broth agar plates by the formation of very narrow, turbid, inhibition zones surrounding the colonies of these strains in the otherwise complete lawr. ofi ndicator B. megaterium Mut. SR. It was subsequently 
found that all organisms in a population of $M A^{-}$bacteria gave rise to colonies which produced these rather indistinct inhibition zones and which were quite unlike those formed by the parent $M^{+}$bacteria. This new antibiotic was active only against strains of $B$. megaterium, although its activity spectrum was quite different from that of megacin A (see below). This new bacteriocin of $\boldsymbol{B}$. megaterium will be described as megacin $\mathbf{C}$.

\section{Table 3. The formation of megacin $C$ in growing cultures of Bacillus megaterium}

$\mathbf{M}^{+}$and $\mathbf{M}^{-}$strains of Bacillus megaterium were grown in nutrient broth at $37^{\circ}$. Optical density measurements made at intervals and samples centrifuged and the supernatant fluid assayed. Megacin $\mathrm{C}$ activity was determined by the method described previously for megacin A (Holland, 1961) but using the strain, highly sensitive to megacin $C$, B. megaterium Mut., as indicator.

B. megaterium strain $33 \mathbf{M}^{+}$

B. megaterium strain $33 \mathrm{MA}^{-}$

\begin{tabular}{|c|c|c|c|c|}
\hline $\begin{array}{c}\text { Time } \\
\text { (hr) }\end{array}$ & $\begin{array}{c}\text { EEL. } \\
\text { (optical } \\
\text { density) } \\
\text { reading }\end{array}$ & $\begin{array}{c}\text { Megacin C } \\
\text { titration }\end{array}$ & $\begin{array}{c}\text { EEL } \\
\text { (optical } \\
\text { density) } \\
\text { reading }\end{array}$ & $\begin{array}{r}\text { Megacin C } \\
\text { titration }\end{array}$ \\
\hline $\mathbf{0}$ & $\mathbf{0}$ & $\mathbf{0}$ & $\mathbf{0}$ & 0 \\
\hline $\mathbf{2}$ & 0 & 0 & 1.5 & 0 \\
\hline $\mathbf{3}$ & 0.5 & 20 & 1.5 & 20 \\
\hline 4 & $9 \cdot 5$ & 400 & 13 & 400 \\
\hline 5 & 36 & 200 & 39 & 200 \\
\hline 6 & 58 & 5 & 63 & 20 \\
\hline 7 & 63 & 0 & 67 & o \\
\hline 8 & 65 & $\mathbf{0}$ & 70 & $\mathbf{0}$ \\
\hline \multicolumn{3}{|c|}{ Strain $40 \mathrm{M}^{+}$} & \multicolumn{2}{|c|}{ Strain $40 \mathrm{MA}^{-}$} \\
\hline $\mathbf{0}$ & $\mathbf{0}$ & $\mathbf{0}$ & o & $\mathbf{0}$ \\
\hline 2 & 0 & 0 & 0 & 0 \\
\hline $\mathbf{3}$ & o & o & $\mathbf{0}$ & $\mathbf{0}$ \\
\hline $4 \cdot 5$ & 14 & $\mathbf{0}$ & 1.5 & 0 \\
\hline 5 & 25 & $\mathbf{0}$ & 5 & $\mathbf{0}$ \\
\hline 6 & $\mathbf{5 2}$ & $\mathbf{1}$ & 29 & $\mathbf{0}$ \\
\hline 7 & 61 & 5 & 59 & 20 \\
\hline 8 & 71 & 1 & 74 & 1 \\
\hline
\end{tabular}

Production of megacin C in liquid medium. By using Bacillus megaterium Mut. SR as indicator organism megacin $\mathrm{C}$ was detected in the supernatant fluids of young cultures of the $M A^{-}$strains, and could also now be detected in cultures of all the corresponding $\boldsymbol{M} \boldsymbol{A}^{+}$original strains. It should be stressed that these results were quite contrary to our earlier findings when, under apparently similar conditions and with the same indicator strain, no soluble antibiotic activity was formed (Holland \& Roberts, 1963). Formation of megacin $\mathrm{C}$ by both $M A^{+}$and $M A^{-}$strains of $B$. megaterium is shown in Table 3 . In the original rapid killers (group 3, megacin Aproducers) and their $\boldsymbol{M A}^{-}$derivatives, megacin $\mathrm{C}$ formation began in the late lag period, reached a maximum in the early exponential phase, but thereafter disappeared rapidly. In only one of the delayed killers (group 2 megacin A-producers) was megacin $\mathrm{C}$ activity found consistently. In this strain, $B$. megaterium 40 , and its $M A^{-}$derivative, megacin $\mathrm{C}$ formation began late in the exponential phase, possibly reaching a maximum in the early stationary phase. Thus there was a clear 
correlation between megacin $\mathbf{C}$ formation and the killing in mixed cultures observed previously with both delayed and rapid killers. None of the non-killers (megacin B producers) formed any megacin $\mathrm{C}$ during growth in liquid media.

\section{Activity spectra of different megacins}

The activity spectra of strains producing megacin $\mathbf{A}$ and $\mathbf{B}$ were determined against 53 strains of Bacillus megaterium as described previously (Methods). The six megacin-A producers tested inhibited the growth of all but two of the $53 \mathrm{~B}$. megaterium strains tested. Ivánovics and co-workers obtained similar results and also found that, with few exceptions, megacin $A$ was not active against other species of bacteria (Nagy, Alföldi \& Ivánovics, 1959; Nagy, 1959). The range of activity of the nine strains which produced megacin $B$ was markedly less than that of megacin A, and only certain strains appeared to be sensitive. Eighteen strains, including all the A-producing strains, were found to be resistant to megacin $\mathbf{B}$. The species specificity of this bacteriocin has not yet been determined.

Although megacin C formation was difficult or impossible to demonstrate on nutrient broth agar, large clear inhibition zones were obtained when Oxoid Nutrient Agar was used. The activity spectra of six megacin C-forming strains, obtained as described above, was determined against 28 strains of Bacillus megaterium. Most non-megacin producing strains were sensitive to megacin C. Some strains especially $B$. megaterium strain Mut., were highly sensitive to megacin $\mathrm{C}$; others, including all the megacinproducing strains, were resistant. The most remarkable feature about the activity spectra of megacin $\mathbf{C}$ was the uniform pattern of activity displayed by different producers. There was also a noticeable absence of reciprocal activity between different producing strains. This suggested that the megacin $\mathrm{C}$ produced by different strains is very similar. In contrast, both A-forming and B-forming strains showed considerable variation in the size and morphology of the inhibition zones produced, and both groups showed strong reciprocal antagonisms when tested against strains which also produced the homologous megacin. This suggests that these groups contain different forms of the particular megacin.

In limited specificity tests megacin $\mathrm{C}$ was found to be inactive against the following organisms overlayered on colonies which produced megacin C: Escherichia coli к 12; Salmonella typhimurium 903; Bacillus cereus, 8012, 7587, 8122; B. subtilis, 1379, 8236.

\section{Megacin C formation by Bacillus megaterium 216}

The properties of Bacillus megaterium 216, the prototype megacin A-producing strain, have been extensively studied (review by Ivanovics, 1962). The formation of megacin $\mathbf{C}$ by this strain is somewhat anomalous and production of the bacteriocin in liquid culture has not been conclusively demonstrated, when either the parent or the $M A^{-}$mutant strains have been tested. A bacteriocin may in fact be formed during growth of non-induced cultures of this organism, but this appears to be predominantly megacin $\mathrm{A}$ and is not liberated by the $\boldsymbol{M A}^{-}$mutant strains. Never-

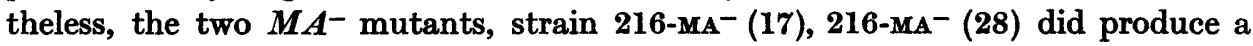
second bacteriocin on solid medium under the same conditions and with an activity 
spectrum identical with those of other megacin C-producing organisms. It is conceivable that in strain 216 megacin $\mathrm{C}$ is tightly bound to the bacteria during liquid culture and is not released into the medium.

\section{DISCUSSION}

The system for colicin classification devised by Fredericq (1953) is based upon cross-resistance tests with bacterial mutants resistant to specific colicins. It has proved impossible to isolate stable megacin (A, B, C) resistant mutants of Bacillus megaterium; similar difficulties in isolation of bacteriocin-resistant strains have been observed with Pasteurella pestis (Burrows \& Smith, 1962 and personal communication), Pseudomonas aeruginosa (Miss A. Patterson, personal communication) and B. megaterium (Professor G. Ivánovics, personal communication). Fredericq (1957) pointed out that colicins classified by use of resistant mutants may differ considerably in chemical and biological properties although having in common the ability to fix to a particular receptor site. Furthermore, grouping by this method breaks down with strains which produce more than one type of bacteriocin. From our studies of bacteriocinogenesis in $B$. megaterium several different types of megacin have been recognized, and, together with the abundant information available from the work of Ivánovics and his colleagues, we feel justified in proposing a preliminary grouping of megacin types. The main criteria for this grouping were: the conditions required for the formation of megacin, the activity spectra, and where possible the mode of action of the megacin. The three types so far recognized have proved to have remarkably consistent group properties and characteristic activity spectra when tested against a range of indicator bacteria. The strains which produce megacin $\mathbf{A}$ were all u.v.-inducible, and in all cases studied in the present work and by Nagy et al. (1959), this megacin destroys the cytoplasmic membrane of sensitive bacteria. The group $B$ megacins are not inducible by u.v. radiation, and have so far only been demonstrated on solid media. Megacins A and B show considerable reciprocal activity within each group and it is apparent that they comprise a number of different types of the same compound. In contrast the $\mathrm{C}$ megacins form a very homogeneous group, different strains apparently producing a similar antibacterial agent. Megacin $\mathrm{C}$ was characteristically produced during logarithmic growth in liquid culture although later it disappeared, perhaps as the result of readsorption to the bacteria. Megacin C, which appears to be a protein whose activity is destroyed by proteolytic enzymes (unpublished) has a mode of action quite different from megacin $A$ and is more reminiscent of colicin (Holland, 1963). The association of megacin $\mathbf{C}$ with u.v.-inducible megacin $\mathbf{A}$ is interesting, but the significance of the association is not yet clear. The two megacin types are, however, separable and there seems no reason why bacteria which produce only megacin $\mathrm{C}$ should not be isolated from nature if the appropriate indicator strain can be found.

It was reported previously that actual cell to cell contact of certain 'killer' $\left(M^{+}\right)$ and sensitive bacteria $\left(M^{-}\right)$of Bacillus megaterium was required for killing to occur (Holland \& Roberts, 1963). This conclusion resulted primarily from experiments in which killing was prevented by separating the $\boldsymbol{M}^{+}$and $\boldsymbol{M}^{-}$bacteria with bacterial filters. At the same time no soluble activity was detectable in either single or mixed cultures containing 'killer' organisms. However, when the experiments were 
repeated several months later killing did occur across bacterial filters and easily detectable amounts of soluble megacin $\mathrm{C}$ were found in the culture medium. This was also the case when cultures of killer strains were grown from dried spore stocks set aside at the beginning of the investigation. It has now been clearly established that the killing factor was a new bacteriocin which we designate megacin $\mathrm{C}$. The killer strains were clearly releasing greater quantities of megacin $\mathbf{C}$ in the later experiments although as far as is possible to ascertain there was no change in cultural conditions. If it be postulated that megacin $\mathrm{C}$, like some colicins, may be a component of the cell surface of the producing bacteria, it is possible that an equilibrium may exist between bound and soluble states. In the current experiments the equilibrium has apparently shifted, in early logarithmic growth, to favour the soluble state. In the latter stages of growth the equilibrium favours the bound form and the megacin is consequently re-adsorbed. There are two, more probable, explanations for the results of the early experiments where an apparent cell contact killing took place. It is possible that very small amounts of the soluble form of megacin $\mathrm{C}$ were present in the cultures and this was prevented from acting across the bacterial filters by adsorption to the filter. Alternatively, the bound form of megacin $\mathrm{C}$ may have been able to kill sensitive organisms as the result of cell to cell contact in mixed culture.

Marjai \& Ivánovics (1962) reported the formation of a bacteriocin by one strain of Bacillus megaterium which has some of the properties of megacin $\mathrm{C}$; it was not u.v.-inducible, but did appear in the early logarithmic cultures and was readily adsorbed by sensitive bacteria. However, this compound was easily sedimented in the ultracentrifuge and it was suggested that it may be a defective phage particle. Megacin $\mathbf{C}$ is not, however, sedimented in the ultracentrifuge (unpublished) and there is no other evidence to suggest that megacin $\mathrm{C}$ is a defective phage particle.

Ivánovics, Alföldi \& Nagy (1959b) suggested that megacin (megacin A) formation is controlled by a highly degraded prophage; nevertheless, this megacin (or any other bacteriocin) does not contain nucleic acid and is therefore quite distinct from bacteriophage. The distinction is not so clear at the genetic level with bacteriocinogenic factors having many of the properties of prophages (cf. Fredericq, 1957; Ivánovics \& Alföldi, 1957; Ivánovies, 1962). It is also difficult to distinguish between bacteriocins and products of highly defective phage particles which lack DNA. Within the scope of our present studies, however, it should be pointed out that the question of nomenclature and whether bacteriocinogenic factors and prophages have evolved in common or independently is not of great signiflcance.

The work was completed during the tenure of a Guinness Research Fellowship in Microbiological Biochemistry (by C.F.R.) and an I.C.I. Biochemistry Research Fellowship (by I.B.H.), and was also aided by grants to the Department from the Rockefeller Foundation and from the United States Department of Health, Education and Welfare. We wish to thank Professor D. D. Woods, F.R.S., for his help and interest and Miss M. J. Edwardson for her skilled technical assistance. 


\section{REFERENCES}

AuföLdr, L. (1958). La production induite de mégacine en milieu synthétique. Ann. Inst. Pasteur, 94, 474.

Alföldi, L., Jacob, F. \& Woluman, E. (1957). Zygose létale dans des croisements entre souches colicinogènes et non colicinogènes d'Escherichia coli. C.r. hebd. Séanc. Acad. Sci., Paris, 224, 2974.

Barky, G. T., Everhart, D. L. \& Graham, M. (1963). Colicine A. Nature, Lond. $198,213$.

Burnows, T. W. \& Smrth, D. A. (1962). Bacteriophage and bacteriocin investigations with Pasteurella pestis and other bacteria. Nature, Lond. 193, 397.

FredericQ, P. (1953). Colicines et bactériophages. Ann. Inst. Pasteur, 84, 294.

Frederice, P. (1954). Induction de la production de colicines par irradiation ultraviolette de souches colicinogènes d'Escherichia coli. C.r. Séanc. Soc. Biol. 148, 1276.

Fredraicq, P. (1955). Induction de la production de colicines et de bactériophages par irradiation ultraviolette de souches colicinogènes et lysogènes d'Escherichia coli. C.r. Séanc. Soc. Biol. 149, 2028.

Frederice, P. (1957). Colicins. A. Rev. Microbiol. 11, 7.

Fredericq, P. \& Betz-Bareau, M. (1953a). Transfert génétique de la propriété de produire un antibiotique. C.r. Séanc. Soc. Biol. 147, 1653.

FredericQ, P. \& Betz-Bareau, M. (1953b). Transfert génétique de la propriété colicinogène en rapport avec la polarité F des parents. C.r. Séanc. Soc. Biol. 147, 2043.

Fredericq, P. \& Betz-Bareau, M. (1956). Influence de diverses propriétés colicinogènes sur la fertilité d'Escherichia coli. C.r. Séanc. Soc. Biol. 150, 615.

Gonber, W. F. \& BArry, G. T. (1958). Colicine K. II. The preparation and properties of a substance having colicine $\mathrm{K}$ activity. J. exp. Med. 107, 185.

Hamon, Y, \& Peron, Y. (1963). Étude du pouvoir bacteriocinogéne dans le genre Listeria. II. Individualité et classification des bactériocines en cause. Ann. Inst. Pasteur, 104, 55.

Holland, I. B. (1961). The purification and properties of megacin, a bacteriocin from Bacillus megaterium. Biochem. J. 78, 641.

Holland, I. B. (1962). Further observations on the properties of megacin, a bacteriocin formed by Bacillus megaterium. J. gen. Microbiol. 29, 603.

HoLLAND, I. B. (1963). Effect of a bacteriocin preparation (megacin C) on DNA synthesis in Bacillus megaterium. Biochem. biophys. Res. Commun. 13, 246.

Holland, I. B. \& Roberts, C. F. (1963). A search for the transmission of megacinogenic factors in Bacillus megaterium. J. gen. Microbiol. 31, xi.

Hutton, J. J. \& Goebel, W. F. (1961). Colicine V. Proc. nat. Acad. Sci., Wash. 47, 1498.

Ivánovics, G. (1962). Bacteriocins and bacteriocin-like substances. Bact. Rev. $26,108$.

Ivánovics, G. \& AlFöLdI, L. (1954). A new antibacterial principle: megacine. Nature, Lond. 174, 465.

Ivánovics, G. \& AlföLdI, L. (1955). Observations on lysogenesis in Bacillus megaterium and on megacine, the antibacterial principle of this bacillus species. Acta microbiol. hung. $2,275$.

Ivánovics, G. \& Alföldd, L. (1957). Bacteriocinogenesis in Bacillus megaterium. J. gen. Microbiol. 16, 522.

Ivínovics, G. \& NAGY, E. (1958). Heriditary aberrancy in growth of some Bacillus megaterium strains. J. gen. Microbiol. 19, 407.

Ivánovics, G., Alföldi, L. \& NAGy, E. (1959a). Mode of action of megacin. J. gen. Microbiol. 21, 51.

Ivánovics, G., AuFöldi, L. \& NaGy, E. (1959b). Masked provirus in Bacillus megaterium strains. Acta virol., Prague, 3, 23.

Јасов, F., Lwoff, A., Siminovitch, L. \& Wollman, E. (1953). Définition de quelques termes relatifs à la lysogénie. Ann. Inst. Pasteur, 84, 222.

Jacob F., Schaeffer, P. \& Wollman, E. L. (1960). Microbial genetics. Symp. Soc. gen. Microbial. 10, 67. 
JACoB, F. \& Wormman, E. L. (1961). Sexuality and the Genetics of Bacteria, p. 93. New York: Academic Press.

Kallenberger, G. \& Krllenserager, E. (1956). Étude de souches colicinogènes au microscope electronique. Schweiz. Z. Path. Bakt. 19, 582.

MaRJaI, E. \& Ivánovics, G. (1962). A second bacteriocin-like principle of Bacillus megaterium. Acta microbiol. hung. 9, 285.

NAGY, E. (1959). Lysogeny and bacteriocinogeny in Bacillus megaterium. Acta microbiol. hung. 6, 337 .

NAGy, E., Alföldi, L. \& Ivánovics, G. (1959). Megacins. Acta microbiol. hung. 6, 327.

Nüske, R., Hösel, G., VenNer, H. \& ZinNer, H. (1957). Über ein Colicin aus Escherichia coli sG 710. Biochem. Z. 329, 346.

Ozeki, H., Stocken, B. A. D. \& De Margerie, H. (1959). Production of colicine by single bacteria. Nature, Lond. 184, 337.

OzekI, H., Howarth, S. \& Clowes, R. C. (1961). Colicine factors as fertility factors in bacteria. Nature, Lond. 190, 986.

Sneath, P. H. A. (1962). Sex factors as episomes. Brit. med. Bull. 18, 41. 